\title{
Guardians of the Corn: The Snake, The Bat and the Toad in Pre-Columbian Mayan Art of the Classic Period (ca. 250-900 CE)
}

\author{
Carey Clements Rote \\ Texas A\&M University, Corpus Christi, TX, USA
}

\begin{abstract}
The conflict and congruity of dualistic approaches to the world inundate the illustration of agricultural production in the Pre-Columbian Art of the Maya. Crop production is co-dependent on human factors, environmental factors and animal factors. The symbiosis of these elements generated success or failure in harmony with the natural world. This paper explores the relationship of three animals to successful crop production with particular attention placed on the cane toad, as this creature has often been confused with frogs or underplayed in earlier academic research. The cane toad is a powerful force in organic farming, functioning as a deterrent to destructive pests. In addition, the cane toad produces powerful hallucinogenic substances for humans, while at the same time, repelling predators with its bitter taste, acrid smell and poison. This bufo-toxin is a powerful substance that links the toad with the Underworld origins of the maize.
\end{abstract}

Keywords: Pre-Columbian, Maya, cane toad, bat, serpent, maize, corn, organic farming, cacao, bufo-toxin

During the Pre-Columbian period in Mesoamerica, corn was the major staple crop. The endurance of the people of Mesoamerica was dependent upon a successful and regular production of maize. Favorable natural conditions, in combination with human and animal interventions, enabled a steady supply of maize for the pre-contact population. Farming was accomplished through two main methodologies (Bassie-Sweet, 2008) including slash and burn technology and terrace farming. Environmental vicissitudes sometimes caused crop production to falter or fail, depleting corn reserves and necessitating interregional cooperation.

Prior to the introduction of Western industrialized farming practices, indigenous farmers relied more heavily on the natural ecosystems to maintain adequate maize production. Farmers turned to natural biological agents to ward off insects and other damaging pests. In particular, serpents, bats and toads contributed to the control of unwanted pests in the cornfields and the storage bins.

In a parallel practice, the ancient human populations in Peru and Bolivia utilized camelid herds to assist in cultivation (Arnold \& Yapita, 2001). Llamas, in particular, were the "compleat" animal of the Andes region, providing for many of the physical needs of the populace. Arnold and Yapita (2001) state that the farming of potatoes would not have been possible without llama dung fertilizer. In deference to the llama, the female herders

Carey Clements Rote, Ph.D., professor, Texas A\&M University, Corpus Christi, TX, USA. Research field: art of ancient. Mesoamerica 
sang a litany of songs to them. In a similar fashion, the bat, the serpent and the toad provided essential protection from unwanted pests in Mesoamerica. Images and myths establish the potent nature of these creatures.

Bassie-Sweet (2008) describes the ploughing of the fields in preparation for corn production as an act fraught with danger due to the abundance of poisonous snakes and other creatures looming on or just underneath the surface of the tilled earth. The farmer, as he ploughed, would literally be taking his life into his own hands. In stark contrast, snakes could also be beneficial to the farmer, particularly after harvest. Rodents are the number one pest of stored corn, so the presence of rodent-eating serpents would have been welcome during this time. This paradigm explicates the dual nature of the serpent, as dangerous and predatory to man, but also as a useful tool in the preservation of harvested, stored corn.

This vase (Figure 1) represents a Maize God impersonator in the maw (mouth) of a serpent. The Maize God figure is seated upon a glyph that represents "Sustenance Mountain", the location where all maize was stored before the beginning of the present era (Brittenham, 2015, p. 203). The "Sustenance Mountain” (Figure 2) has a cleft in the head which identifies it with a volcano (Headrick, 2007, p. 114). Volcanoes nurture the soil with their fertilizing eruptions - a connection clearly understandable to the ancient farmers of Mesoamerica.

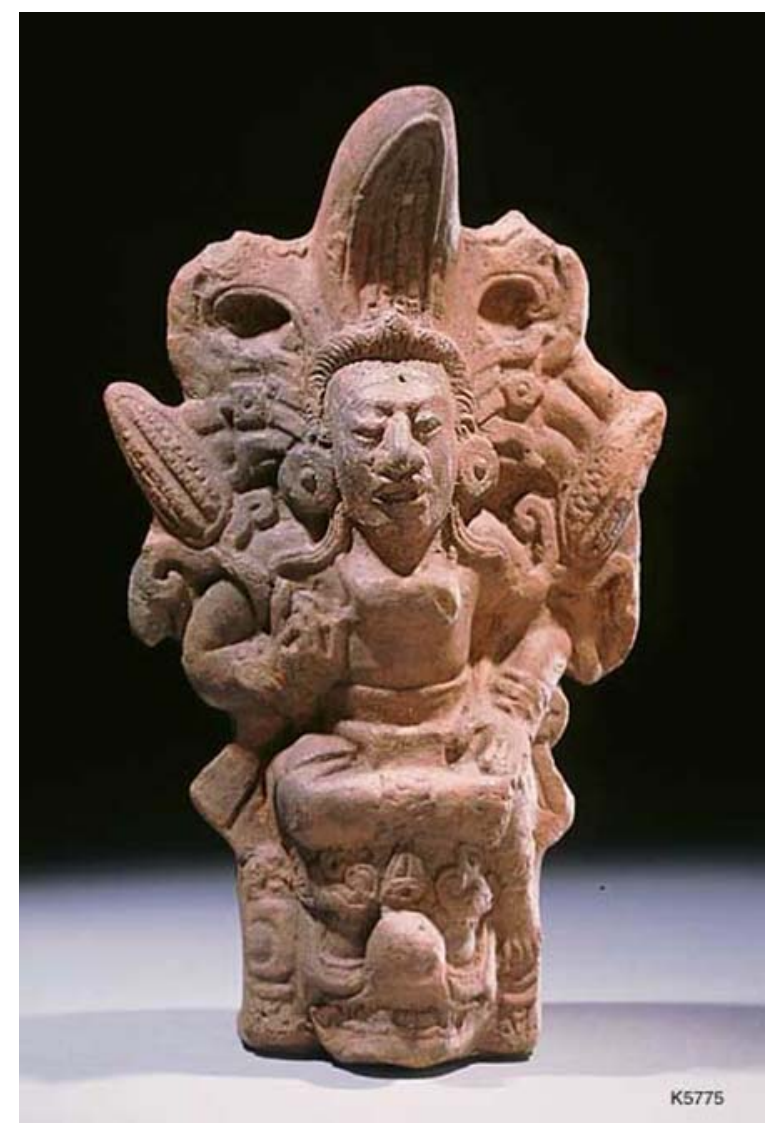

Figure 1. Kerr vessel K5775.

In some representations of the Maize God, cacao pods adorn the images. In Figure 3, the Maize God is shown emerging from the Underworld, the space below "Sustenance Mountain", where corn originated. The image of corn and cacao together binds the two most important crops for the Maya. The two crops, maize and 
cacao, represent dualities in a number of different ways. Grofe (2007, pp. 32-33) draws a parallel between cacao and corn, indicating both crops were believed to have originated from the Underworld. In spite of this mythical Underworld connection, the actual production of maize and cacao expresses the divergent nature of the two crops (Bassie-Sweet, 2008; Britttenham, 2015).

Table 1

Dualities of Maize and Cacao

\begin{tabular}{|l|l|}
\hline Characteristics of maize & Characteristics of cacao \\
\hline Hard to grow & Easy to grow \\
\hline Easy to process & Hard to process \\
\hline For all people & Reserved for upper class \\
\hline Grown in the sun & Shade grown under “madres de cacao" \\
\hline Color like flesh & Turns red when ripe-heart blood \\
\hline Kernels are bones or teeth & Heart blood \\
\hline Corn silk = hair & Blood \\
\hline
\end{tabular}

These last characteristics, describing flesh and blood, reflect the animate nature of both crops. Like humans, these crops are born from the Underworld, representing the character of the world as a living, moving entity in a constant state of flux and change, metamorphosing from one form into another. Man, along with his gods and the animals provided by the gods, must battle change to sustain human life.

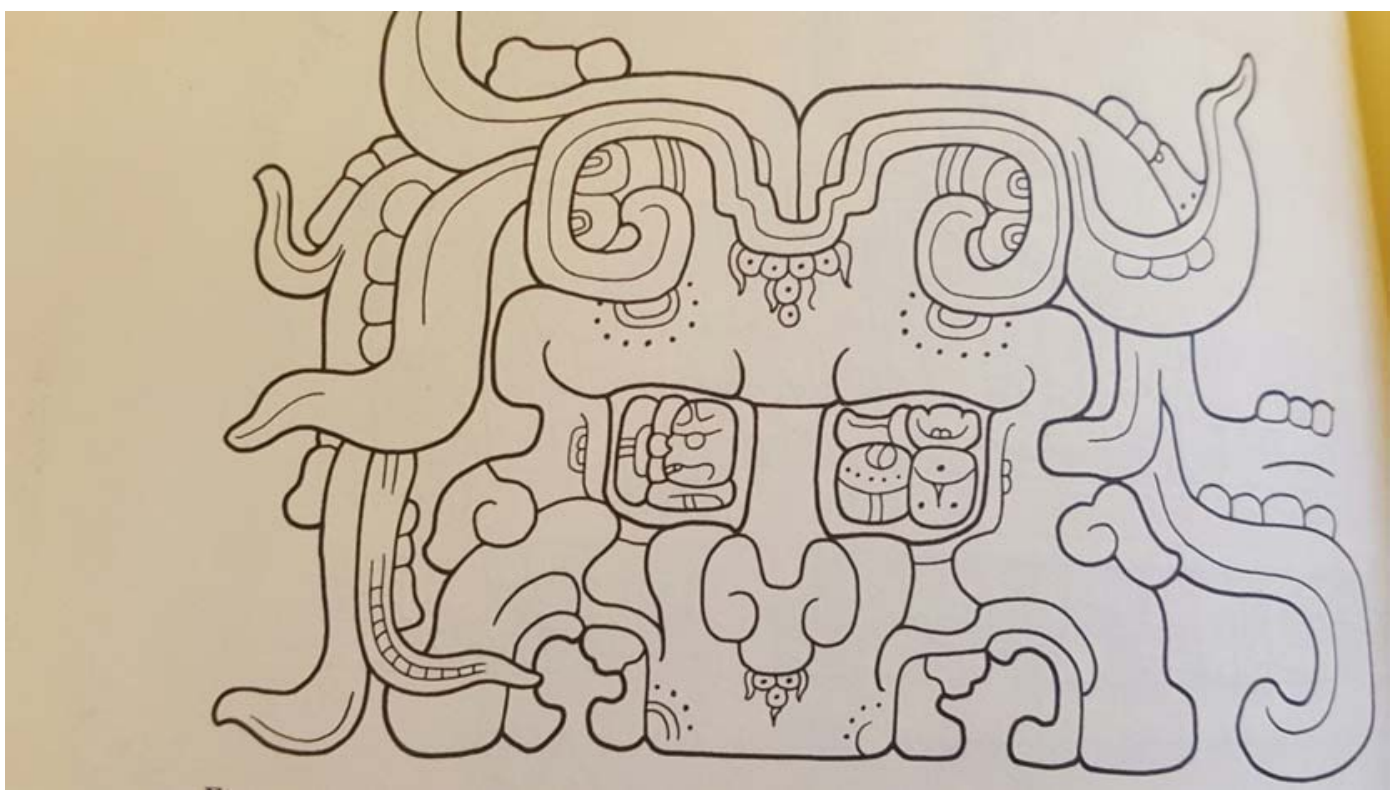

Figure 2. Sustenance Mountain glyph. 


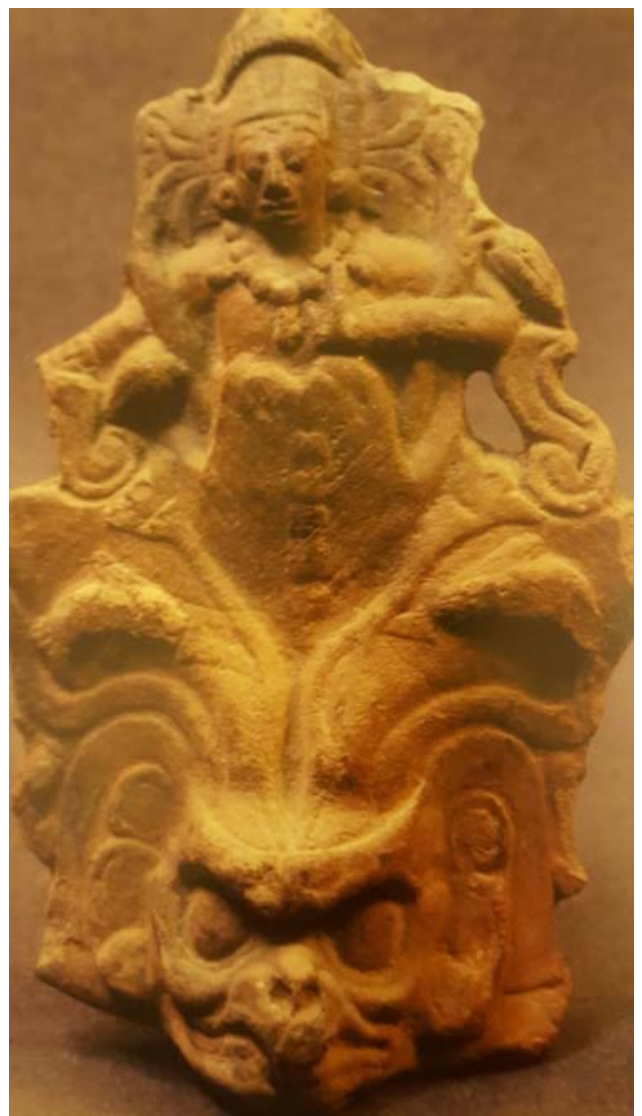

Figure 3. Late Classic Maya ceramic whistle, maize god emerging from Sustenance Mountain with cacao pods attached to his body.

The role of the animals in this process of cultivation and sustenance is further solidified by the Popol Vuh, the sacred Mayan text (Nelson, 1976). In this text, animals transport messages from the Underworld to the gods and the Hero Twins. As we can see in the following diagram, the process of transference is as follows:

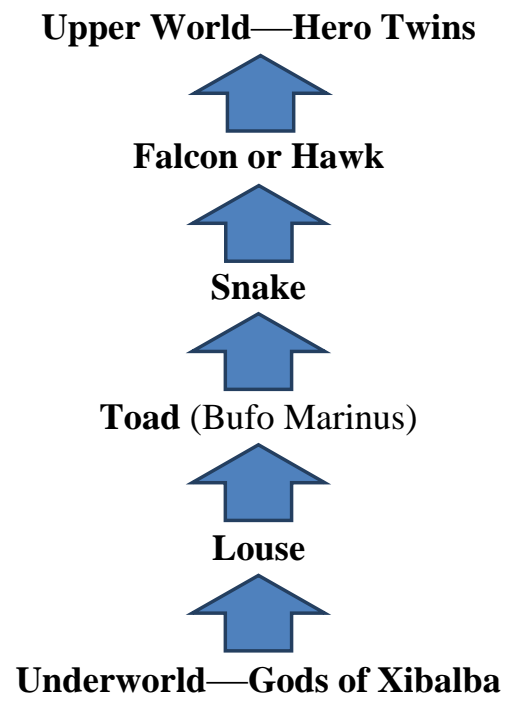

The animal messengers that lead to the Upper World where the Hero Twins reside, swallow each other as 
they progress closer to the twins. The louse is swallowed by the toad, which is swallowed by the snake, which is swallowed by the falcon or hawk, who arrives finally with the message of the Underworld gods to the Hero Twins (Hellmuth, 2011). The toad acts as a mediator between the Underworld, the Earth and the heavens, being of the water, the land and within the belly of the falcon or hawk, also of the heavens.

As stated by Karen Bassie-Sweet in Maya Sacred Geography and the Creator Deities (2008), corn production was conducted either through slash and burn methods or through the building of terraces. In both instances, the farmers would have been more susceptible to environmental vicissitudes. Under several different sets of circumstances, crop production could falter and food would be scarce.

Prior to the introduction of Western industrialized farming practices, indigenous farmers relied more heavily on a natural eco system to help them maintain healthy plants. And at the center of this corn production was maize. As the most important food staple in the Mesoamerican world, it was important to ensure the production of adequate corn to provide for the entire populace. Farmers turned to natural biological agents to ward off insects and other damaging pests. In particular, serpents, bats and toads contributed to the destruction of pests, in addition to the function of serpents in the guarding of stored corn (as mentioned above).

Bassie-Sweet (2008) describes the ploughing of the field for corn as adangerous act due to the disruption of snakes and other poisonous creatures looming on or just underneath the surface of the earth. Rodent-eating snakes would have proven beneficial to the crops. The number one pest of corn after it is harvested and stored are rats and mice. A Maize God impersonator rests comfortably in the maw of a serpent (Figure 1). The Maize God is seated upon a glyph that represents "Sustenance Mountain", the sacred place from which corn derives. It has a cleft in the head, symbolically portraying a volcano.Volcanic eruptions nourished the soil, allowing crops to grow more abundantly.

The second beneficial creature in the control of pests preying on maize crops is the bat. There are numerous species of bats throughout Mesoamerica. Their ancient populations must have been massive. Recent conservation efforts by organizations like Bat Conservation International have helped to re-propagate many bat species. Bat Conservation International also conducts research on the environmental impact of bats. BCI recently featured a study published in the Proceedings of the National Academy of Sciences (Bat Conservation International, 2015). This research revealed that bats play a significant role in combating corn pests, saving more than $\$ 1$ billion a year in crop damages around the world today. In the study, crops protected by bats were not destroyed by the corn earworm. The corn earworm is a moth whose larvae feed on ears of corn, causing direct damage to yield, but also introducing an avenue for infection of the corn ear by fungi, which produces compounds that are toxic to humans and livestock. The Mesoamerican inhabitants were aware of the beneficial aspects of these night feeders, worshipping them as dangerous, but also helpful creatures.

Bats appear in numerous images in Pre-Columbian Mesoamerican art. In many instances, images that have been identified as jaguars often appear to represent bats on closer inspection. This conflation of the two forms is logical, in that composite animals and composite human/animals are found frequently in Pre-Columbian art. These dual or triple images also relate to the transformative experiences of humans to their animal doubles or naguales. Zapotec bat god urns also have jaguar-like characteristics. In addition, incensarios discovered in Veracruz show conflated and stylized representations that may encompass parts of several different animals. Also from Veracruz, is a warrior wearing the mask of a leaf-nosed bat. 
Another possible bat image appears in the Temple of the Owls at Chichén Itzá (Figure 4). Identified as owls, these figures have similarities to bat renditions. I have included here a bat from Copán for comparison with these "owl” images (Figure 5). The Maize Tree combined again with cacao imagery is found on the front portion of these piers from the Temple of the Owls. Simon Martin also reproduces a now destroyed painted capstone from this same building in his article entitled, "Cacao in Ancient Maya Religion: First Fruit from the Maize Tree and other Tales from the Underworld” (2006). This scene represents God K or K’awil emerging from the Underworld. K'awil is the god of lightning, serpents, fertility and maize, thus conflating the serpent with maize once again. K'awil here emerges from the open mouth of a serpent, flanked by owl/bat messengers from the Underworld.

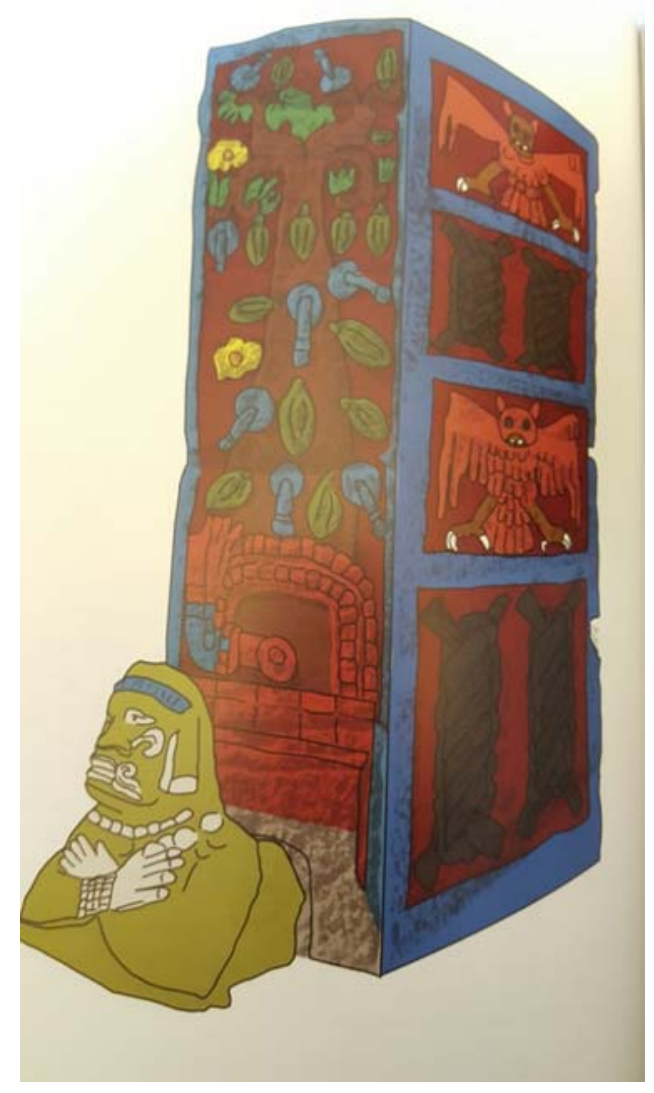

Figure 4. Temple of the Owls, Chichén Itzá.

The third creature tied to corn production is the toad (and the frog). This paper will specifically focus on cane toads, but frogs are also important harbingers of rain. In other indigenous corn-producing cultures, like the Acoma and the Zuni pueblos, frogs appear in works of art tied to maize production (Sotheby's, 2011). Both frogs and toads are transformative, changing from eggs to tadpoles to froglets/toadlets to frogs/toads at the beginning of the rainy season. Their metamorphoses herald the advent of the rainy season. Their appearance as transformed creatures welcomed the time of planting. Like bats, these amphibians consume large amounts of insects, protecting the corn crops (Figure 6). 


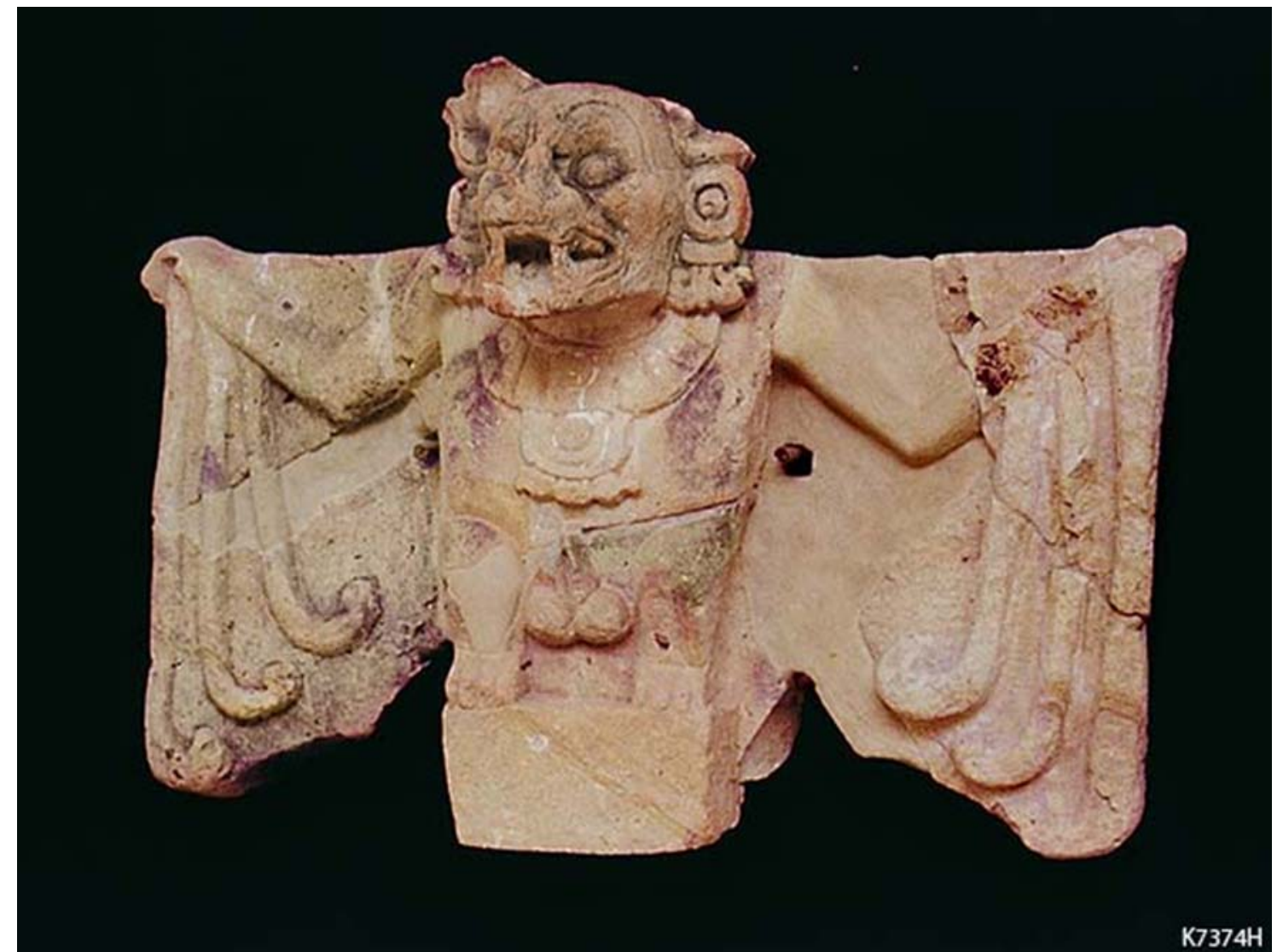

Figure 5. K7374H Copán bat effigy. 


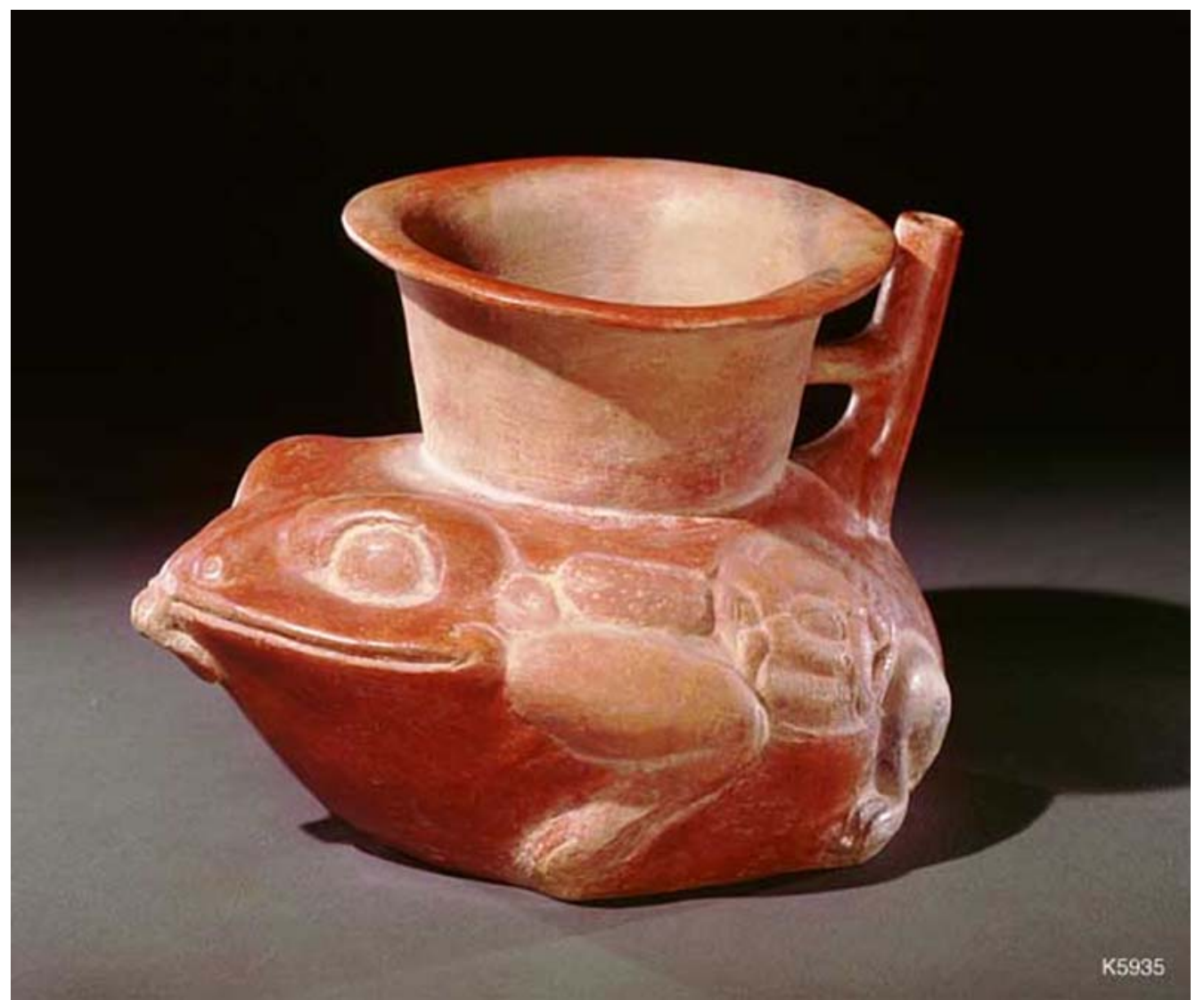

Figure 6. K5935 toad vessel.

Some varieties of toads have poison sacks containing hallucinogenic and deadly substances. These images of toads show the sacks on their backs. Looking through these renditions, we see the frogs becoming increasingly happy, with some frogs sporting silly grins, mimicking the high achieved by humans from the ingestion of their poison sacks. The toad in this bowl emerges from the water at the quadripartite opening to the other world, emerging from the Underworld, in the beginning of his transcendent journey to the Hero Twins (Figure 7). 


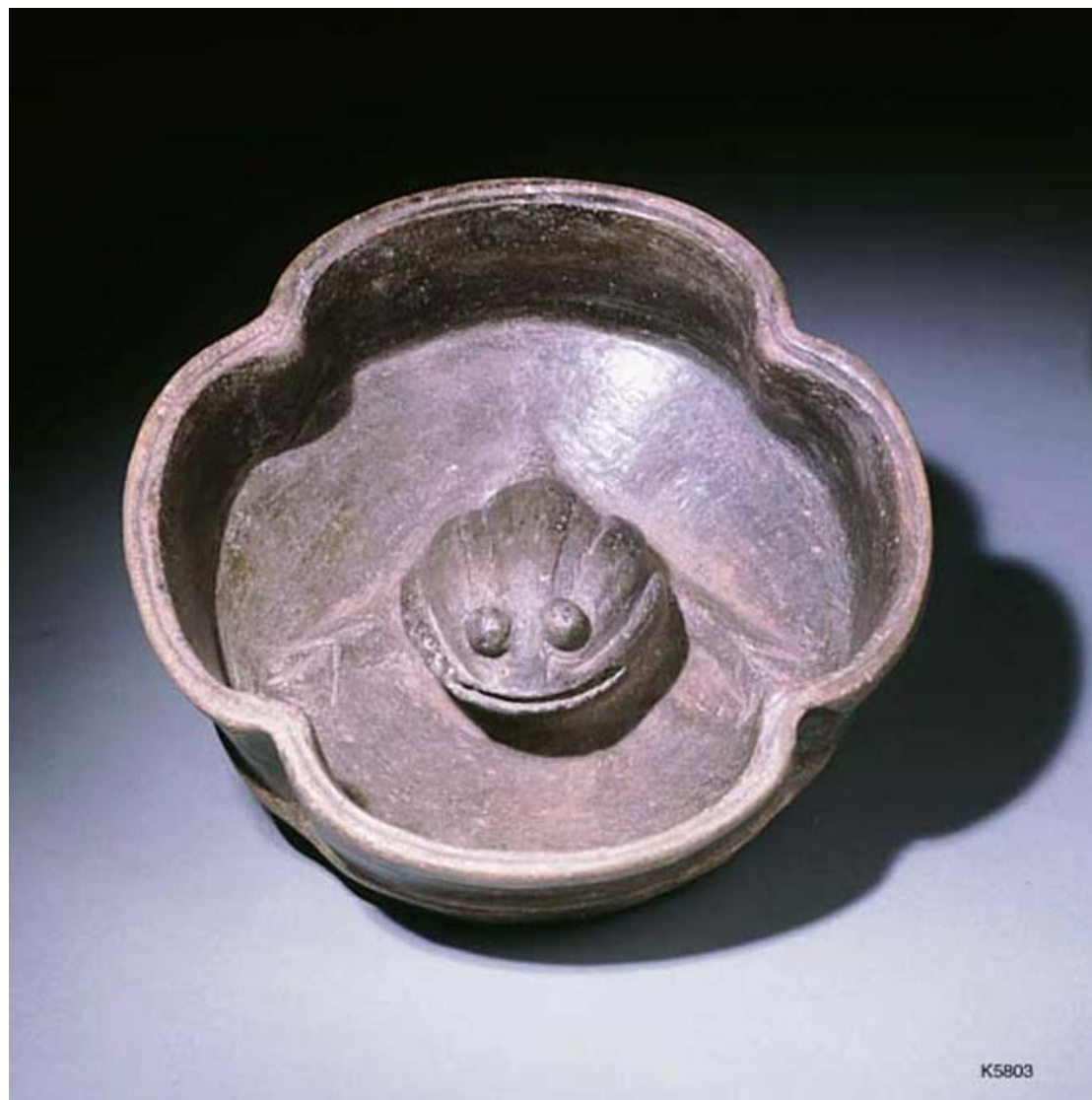

Figure 7. K5803 toad emerging out of the Underworld.

In 1975, a large Maya mural program was uncovered at Cacaxtla in Puebla, Central Mexico. Some of these murals depict a battle between two opposing groups. Jaguar-clad warriors battle to the death with bird warriors. In addition to the battle narrative, other murals at the site present religious and political visual rhetoric, extolling the maintenance of a balance in the world to provide for the needs of mankind.

One temple, known as the Red Temple, has two toads that guard its underground entrance (Figure 8). Placed on either side of the entrance stairs, the toads are perched on flowing water filled with turtles, aquatic birds and star/Venus symbols. Rain drops fall from the sky in this part of the image, landing on maize plants that contain miniature heads of the Maize God in place of ears. Directly behind the maize plants is a cacao tree, with a bird alighting on that tree. Behind the cacao plant, is a trader with a pack resting behind him. 


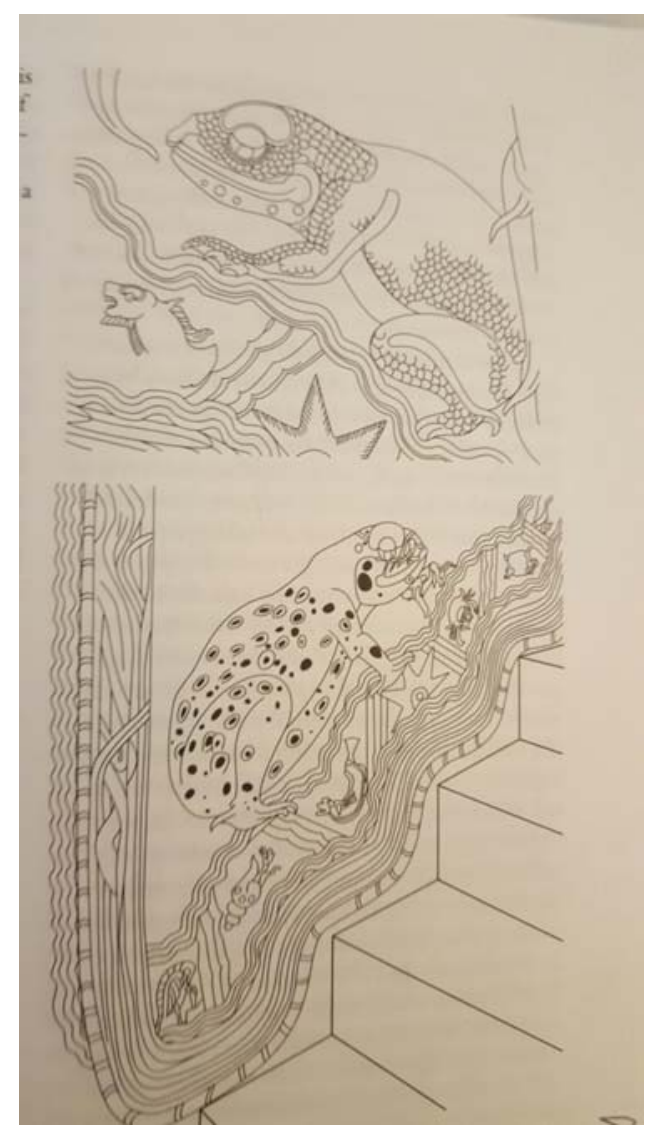

Figure 8. Male and female toads from Red Temple, Cacaxtla.

The two toads at the entrance are cane-toads (rhinella marina). They represent male and female cane toads. The male is larger and has smoother skin and fewer spots than the female at the bottom. These toads grow to a very large size, the largest weighing in at almost 6 pounds.

In addition, these toads have sacks of neurotoxin (a form of DMT, a powerful psychedelic) directly behind their eyes. This bufotenin or "bufo-toxin" was dried and used in Pre-Columbian rituals of transformation in which rulers and priests communicated with the deceased ancestors in an altered state of consciousness. The cane toad was sacred because of its ability to control insect populations, as well as its hallucinogenic qualities. The amount of toxin in one toad was enough to kill a large man. If an animal were to accidentally ingest one of these toads it would die. As such, the toad is transformative and dangerous—connecting the living and the dead.

The cane-toad also has other properties that link it to the star/Venus symbols in the murals of the Red Temple. The eggs of toads are clear with a black dot in the middle. These eggs are produced in strips, numbering in the thousands, mimicking the stars in the sky and/or jaguar spots. The cane-toad also resembles the Were-Jaguar because of these spots. The smaller female toad has three fangs, further tying her to the Were-Jaguar. Also, the temple is dedicated to Venus. As "morning star", Venus functionally pulls the sun from the underworld each day, much like a tadpole emerges out of the water as a toad. The toad imagery in this temple compliments the dualities expressed throughout the site: female vs. male, living vs. dead and Venus vs. the Sun (Neal, 2015).

In contemporary natural farming, toads are used in agricultural fields as an important form of "biological control" (Waage \& Greathead, 1988). Like bats, toads provide an alternative to the use of pesticides, helping to 
maintain a natural balance first observed in ancient times.

Toads, as bearers of hallucinogenic substances, enter the Underworld, and party with other creatures. In this drinking vessel from LACMA, we see a toad presenting a bone, an eyeball and a human hand as a gift in a bowl. Here, the serpent and the jaguar join the ecstatic event (Figure 9). Together, the three bridge the watery Underworld (toad), the earthly realm (jaguar) and the sky (serpent). The jaguar dances to a conch shell trumpeter emerging from the mouth of the serpent. Ecstatic rituals performed by the elite (disguised as their animal spirit doubles or naguales) ensure the prosperity of the earthly environment.

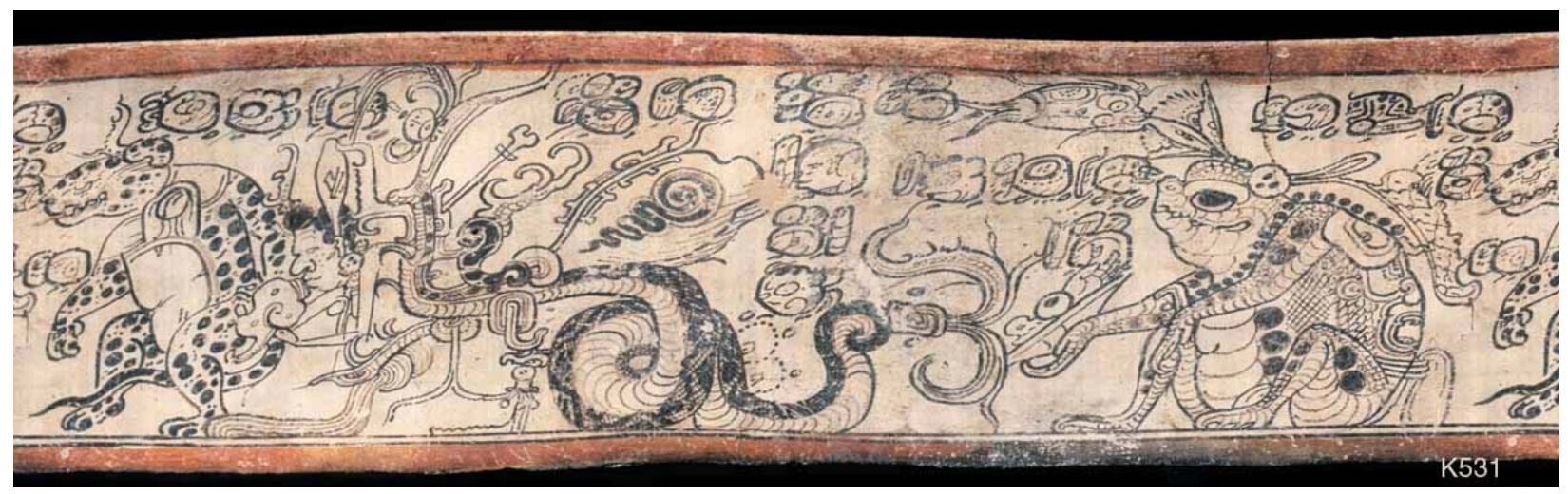

Figure 9. K531, toad, serpent and jaguar.

The toads, as other animals, emphasized the deep connections the indigenous people had with the natural world. They understood the dual nature of many animals, terrifying to humankind, but also useful to them. Rulers exacted blood from the populace to aid in the growth and sustenance of crops. The blood and the natural cycle combined to create a vibrant system of cultivation. Maize production achieved paramount importance in the food chain. Carvings and murals of toads, bats and snakes reflect the importance of these native animals as biological agents to ward off pests and protect the corn.

Warfare and famine weighed heavy on the kings and priests of Cacaxtla and other sites. Steps had to be taken to ensure the crops generated a viable amount of food for their communities. Serpents and bats protected the corn through their natural habits. The toad was a particularly beneficial creature in the many roles that it maintained. The toad announced the rains, fed on damaging insects and served as the source for a powerful drug used by elites in rituals and sacrifices. Jointly, religious beliefs, rituals and agricultural methods guaranteed a successful harvest, making snakes, bats and toads guardians of the corn.

\section{References}

Arnold, D. Y., \& Yapita, J. D. (2001). River of Fleece, River of Song: Singing to the animals, an Andean poetics of creation. Bonn Americanist Studies, 35, 9-408.

Bassie-Sweet, K. (2008). Maya sacred geography and the creator deities. Norman, Oklahoma: University of Oklahoma Press.

Bat Conservation International. (2015, September 14). Bats worth over \$1 billion to corn industry. Retrieved from batcon.org: http://www.batcon.org/resources/media-education/news-room/gen-news/80-latest-news/930-bats-worth-over-1-billion-to-cor n-industry

Brittenham, C. (2015). The murals of Cacaxtla: The power of painting in Ancient Central Mexico. Austin, Texas: The University of Texas Press.

Grofe, M. J. (2007). The serpent series: Precession in the Maya Dresden Codex (PhD dissertation). University of California at Davis. 
Headrick, A. (2007) The Teotihuacan Trinity: The sociopolitical structure of an ancient Mesoamerican city. Austin: The University of Texas Press.

Hellmuth, N. M. (2011, February 1). Sacred toads. Revue Magazine, pp. 1-5.

Neal, R. T. (2015). Toads at Temple of Venus. Corpus Christi, Tx.: Unpublished.

Nelson, R. (1976). Popol Vuh: The great mythological book of the Ancient Maya. Boston: Houghton Mifflin Company.

Pleasant, J. (2015). A new paradigm for Pre-Columbian agriculture in North America. Early American Studies: An Interdisciplinary Journal, 13(Spring), 374-412.

Sotheby's. (2011, May 18). Sotheby's American Indian art auction. Retrieved from Sotheby's catalogue: http://www.sothebys.com/en/auctions/ecatalogue/2011/american-indian-art-n08752/lot.125.html

Waage, J. K., \& Greathead, D. J. (1988). Biological control: Challenges and opportunities [and discussion]. Philosophical Transactions of the Royal Society of London. Series B, Biological Sciences 318, 111-128. 